\title{
Peningkatan Prestasi Belajar Ipa Dengan Strategi Mengoptimalkan Media Gambar Dan Audiovisual Di Kelas V SDIT Harapan Bunda Purwokerto
}

\section{Anggun Suryandari}

\author{
SDIT Harapan Bunda Purwokerto
}

anggunsuryandari@gmail.com

\section{Article History}

received 3/12/2020

\begin{abstract}
The paper describe about result from classroom action research is based on the low student learning scores on science subject on grade V SDIT Harapan Bunda Purwokerto. The author tries to examine the causes of the low students achievement and find a problem solving. The subject matter of this study is guite simple, namely the optimization strategy of image and audio visual media to determine the improvement of student learning result in science subject about blood circulation. This research was carried out in two cycles that were preceded by a pre-cycle, carried out in September 2016. Cycle 1 was carried out on September 5, 2016 and cycle 2 wa carried out on September 26, 2016. In the first and second cycles, the strategy used was the strategy of optimizing image media and audiovisual media. The result showed an increase student achievement. It is evident from the average valueof class in the initial conditions is 70,0 , in the first cycle is 76,2 and the second cycle is 88,1 .
\end{abstract}

Keywords: image and audiovisual media, student learning outcomes

\begin{abstract}
Abstrak
Tulisan ini menjelaskan tentang hasil dari Penelitian Tindakan Kelas yang berlatar belakang pada rendahnya nilai belajar siswa pada pelajaran IPA di kelas V SDIT Harapan Bunda Purwokerto. Penulis mencoba menelaah penyebab rendahnya nilai belajar siswa serta mencari jalan keluarnya. Materi pokok kajian ini cukup sederhana yaitu stretegi pengoptimalan media gambar dan audiovisual untuk mengetahui peningkatan hasil belajar siswa pada mata pelajaran IPA tentang peredaran darah. Penelitian ini dilaksanakan dalam dua siklus yang didahului dengan pra siklus, dilaksanakan bulan September 2016. Siklus 1 dilaksanakan pada tanggal 5 September 2016 dan siklus 2 dilaksanakan pada tanggal 26 September 2016. Pada siklus I dan II strategi yang digunakan adalah mengoptimalkan media gambar dan audiovisual. Hasil penelitian menunjukkan terjadi peningkatan belajar siswa. Terbukti dari nilai rata-rata kelas pada kondisi awal adalah 70,0 pada siklus 1 adalah 76,2 dan pada siklus 2 adalah 88,1.
\end{abstract}

Kata kunci: media gambar dan audiovisual, hasil belajar siswa.

Social, Humanities, and Education Studies (SHEs): Conference Series https://jurnal.uns.ac.id/shes

p-ISSN 2620-9284

e-ISSN 2620-9292 


\section{PENDAHULUAN}

Pendidikan menurut Ki Hajar Dewantara dalam Kongres Taman Siswa yang pertama pada tahum 1930 menyebutkan: Pendidikan umumnya daya upaya untuk memajukan pertumbuhannya budi pekerti (kekuatan batin, karakter), pikiran (intelek), dan tubuh anak; dalam Taman Siswa tidak boleh dipisah-pisahkan bagian-bagian itu agar memajukan kesempurnaan hidup, kehidupan dan penghidupan anak-anak yang kita didik selaras dengan dunianya (Djaelani: 2015: 5).

Pendidikan merupakan kebutuhan primer yang mempunyai peranan yang sangat penting dalam mendidik manusia menjadi lebih baik, karena hasil yang diharapkan dari sebuah pendidikan atau pembelajaran meliputi tiga aspek yaitu aspek kognitif meliputi perubahan dalam segi penguasaan ilmu pengetahuan dan perkembangan ketrampilan yang diperlukan untuk menggunakan pengetahuan tersebut, aspek afektif meliputi perubahan segimental, perasaan dan kesadaran dan aspek psikomotorik meliputi perubaan dalam seti tindakan bentuk psikomotorik (Darajat, 1995).

Proses pendidikan diselenggarakan secara formal di sekolah, dimaksudkan untuk mengarahkan perubahan pada diri seseorang secara terencana, baik dalam aspek pengetahuan, keterampilan maupun sikap. Dalam proses mengajar terdapat lima komponen yang penting yaitu tujuan, materi, metode, media dan evaluasi pembelajaran dimana komponen yang satu saling mempengaruhi komponen yang lain.

Media sendiri adalah alat yang menyampaikan atau menghantarkan pesanpesan pembelajaran. Kata media berasal dari bahasa Latin medius yang secara harfiah berati 'tengah', 'perantara' atau 'pengantar. Gearlach \& Ely mengatakan bahwa media apabila dipahami secara garis besar adalah manusia, materi atau kejadian yang membangun suatu kondisi yang membuat siswa mampu memperoleh pengetahuan, keterampilan atau sikap. Atwi Suparman mendefinisikan, media merupakan alat yang digunakan untuk menyalurkan pesan atau informasi dari pengirim kepada penerima pesan (Faturohman: 2007)

Dilihat dari jenisnya, media dibagi kedalam media auditif, visual dan Audiovisual. Media auditif adalah media yang hanya mengandalkan kemampuan suara saja, seperti radio,cassete recorder, piringan hitam. Media visual adalah media yang hanya mengandalkan indera penglihatan. Media visual ini ada yang menampilkan gambar atau simbol yang bergerak seperti film strip (film rangkai), foto, gambar atau lukisan, cetakan.

Penggunaan media yang tepat selain untuk mempermudah pendidik menyampaikan materi kepada peserta didik tetapi juga penggunaan media pembelajaran membantu untuk meningkatkan keaktifan peserta didik yang akan berdampak pada hasil belajar peserta didik. Kemp dan Dayton (Sutiman: 2013) mengidentifikasikan delapan manfaat media dalam pembelajaran, yaitu:

a. Penyampaian pembelajaran menjadi lebih baku

b. Pembelajaran cenderung lebih menarik

c. Pembelajaran menjadi lebih interaktif

d. Lama waktu pembelajaran dapat dikurangi

e. Kualitas hasil belajar siswa lebih meningkat

f. Pembelajaran dapat berlangsung dimana dan kapan saja

g. Sikap positif siswa terhadap materi belajar dan proses belajar dapat ditingkatkan

h. Peran guru dapat berubah kearah yang lebih positif

Sedangkan prestasi belajar adalah penguasaan pengetahuan atau ketrampilan yang dikembangkan oleh mata pelajaran yang lazimnya ditunjukkan dengan nilai tes atau angka nilai yang diberikan guru (Kamus Besar Bahasa Indonesia, 2002: 895)

Hasil belajar atau prestasi belajar dipengaruhi oleh beberapa faktor. Menurut Ngalim Purwanto (2011) terdapat dua faktor yang mempengaruhi prestasi belajar seseorang, yaitu:

a. Faktor belajar dari luar, meliputi: 
1) Lingkungan

Lingkungan alam maupun lingkungan sosial dapat mempengaruhi prestasi belajar.

Semakin kondusif lingkungan yang ditempati, prestasi belajar semakin bagus.

2) Instrumental

Faktor instrumental ini terdiri dari kurikulum/bahan ajar, guru, sarana dan fasilitas serta administrasi.

b. Faktor belajar dari dalam, meliputi:

1) Fisiologis (kondisi fisik dan kondisi panca indra)

2) Psikologis yang terdiri dari bakat, minat, kecerdasan, motivasi dan kemampuan kognitif.

Berdasarkan pengalaman tahun lalu pencapaian ketuntasan pelajaran IPA kelas $V$ di SDIT Harapan Bunda Purwokerto belum 100\%, rata-rata dibawah 70,0 dibawah KKM yang ditentukan yakni 75,0. Ditinjau dari segi guru, penyampaian materi lebih banyak berupa ceramah. Guru belum mengoptimalkan media visual dan audiovisual, sehingga siswa mengalami kebosanan yang berimbas pada pencapaian hasil belajar siswa.

Permasalahan tersebut menurut peneliti dapat diatasi dengan strategi mengoptimalkan media visual dan audiovisual yang diharapkan seluruh siswa dapat menyerap informasi dan dapat meningkatkan hasil belajar siswa.

Piaget (dalam Sujana, 2014, hlm. 27) membagi skema yang digunakan anak untuk memahami dunianya melalui empat periode utama, yaitu periode sensorimotor (0-2 tahun), periode praoperasional (7-7 tahun), periode operasional konkrit (7-11 tahun), serta periode operasional formal (11 tahun sampai dewasa). Pada periode operasional konkret berangsung sekitar 7-11 tahun. Pada usia ini adalah usia anak sekolah SD. Pada usia ini pikiran logis anak mulai berkembang dan mulai menggali informasi tentang lingkungannya tidak dengan panca inderanya saja. Anak pada usia ini sudah dapat berpikir secara operasi konkret. Anak telah dapat melakukan klasifikasi, pengelompokan dan pengaturan masalah (Fujiyanto, 2016).

Dalam pembelajaran IPA menurut Sujana (2014, hlm. 44) terdapat beberapa proses sains yang dapat diaplikasikan pada siswa Sekolah Dasar yaitu, Mengamati, pengukuran, interpretasi atau menasirkan, klasifikasi atau pengelompokkan, prediksi dan berkomunikasi. Dari penjelasan tersebut dapat disimpulkan bahwa dalam proses dasar sains harus meliputi salah satu aspek sains yaitu mengamati, pengukuran, interpretasi atau menafsirkan, klasifikasi atau pengelompokkan, prediksi, dan berkomunikasi dalam menyampaikan materi dalam IPA. Dalam materi peredaran darah dibutuhkn suatu pengamatan dalam bentuk kongkrit. Dimana aktifitas ini dapat dipermudah menggunakan media gambar dan media audiovisual.

Media visual merupakan media yang hanya melibatkan indera penglihatan, termasuk dalam jenis media ini adalah

1. media cetak-verbal (pesan berbentuk tulisan)

2. media cetak-grafis (gambar, sketsa, lukisan, foto, grafik, diagram, bagan dan peta)

3. media visual non cetak (miniatur, specimen dan diorama).

Media audio visual adalah media yang mempunyai unsur suara dan unsur gambar (Bahri, 2010). Menurut Yusuf Hadi Miarso, media audiovisual mempunyai fungsi sebagai berikut:

1) media mampu memberikan rangsangan yang bervariasi pada otak, sehingga otak dapat berfungsi secara optimal.

2) media membangkitkan motivasi dan merangsang untuk belajar.

3) media memberikan pengalaman yang integral dari sesuatu yang konkret maupun abstrak.

4) media membangkitkan keinginan dan minat siswa. 
5) media memberikan kesempatan siswa untuk belajar mandiri, pada tempat dan waktu serta kecepatan yang ditentukan sendiri.

\section{METODE}

Penelitian ini merupakan Penelitian Tindakan Kelas (PTK). Tindakan dalam penelitian adalah pengoptimalan media gambar dan audiovisual untuk mata pelajaran IPA. Tempat penelitian ini adalah SDIT Harapan Bunda Purwokerto yang beralamat di Jl. K.H. Wahid Hasyim gang Pesarean Kalangklesem, Kecamatan Purwoketo Selatan, Kabupaten Banyumas, Provinsi Jawa Tengah. Subjek penelitian ini adalah peserta didik kelas V SDIT Harapan Bunda Purwokerto sebanyak 21 siswa.

Teknik pengumpulan data dilakukan dengan teknik tes. Teknik tes yang dilakukan adalah dengan memberikan tes tertulis kepada siswa. Hal ini untuk mengetahui hasil belajar siswa yang berupa nilai. Alat pengumpulan data berupa butir soal tes yang digunakan sebagai alat pengumpul data dalam mengukur hasil belajar siswa pada mata pelajaran IPA setelah dilakukan tindakan. Sumber data yang digunakan adalah sumber data primer yang berupa nilai tes siswa khusus pada aspek pemahaman konsep. Penelitian ini menggunakan validasi butir soal yang dilakukan dengan menyusun kisi-kisi butir soal sebelum menyusun butir soalnya agar sesuai dengan indikator pencapaian kompetensi dan standar kompetensinya jelas. Sehingga butir soal yang tersusun menjadi alat pengukur data yang akurat dan valid. Penelitian ini juga menggunakan analisis data primer yang dilakukan dengan membandingkan nilai hasil belajar sebelum dan sesudah siklus.

\section{HASIL DAN PEMBAHASAN}

tPenelitian dilaksanakan di kelas V SDIT Harapan Bunda Purwokerto dengan jumlah peserta didik sejumlah 21 siswa. Pembelajaran pada siklus 1 berkaitan dengan materi peredaran darah pada manusia. Media yang digunakan berupa video pembelajaran yang diambil dari youtube. Pembelajara menjadi menarik karena media yang digunakan menampilkan video yang relefan dengan materi yang di[elajari. Berikut ini akan disajikan tabel yang berisikan peningkatan hasil belajar siswa.

Tabel 1. Peningkatan Hasil Belajar Siswa

\begin{tabular}{ccccc}
\hline \multirow{2}{*}{ No } & \multirow{2}{*}{ Nilai } & \multicolumn{3}{c}{ Frekuensi (jumlah siswa) } \\
& & Pra Siklus & Siklus 1 & Siklus 2 \\
\hline 1 & 50 & 2 & - & - \\
2 & 60 & 2 & 2 & - \\
3 & 70 & 11 & 8 & - \\
4 & 80 & 6 & 7 & 8 \\
5 & 90 & - & 4 & 9 \\
6 & 100 & - & - & 4 \\
& Jumlah & 1470 & 1600 & 1850 \\
& Rata-rata & 70,0 & 76,2 & 88.1 \\
\hline
\end{tabular}

Aktifitas pada siklus I adalah 1) peserta didik mengamati video tentang sistem peredaran darah yang ditampilkan melaui layar proyektor dengan perhatian yang baik. 2) Peserta didik mengkomunikasikan isi dari video pembelajaran yang sudah diamati dengan bahasa yang baik. 3) Peserta didik menjawab pertanyaan lisan yang diajukan guru seputar video yang diamati. 4) Peserta didik menjawab pertanyaan tertulis yang sudah disiapkan guru guna mengetahui tingkat pemahaman siswa terhadap materi yang dipelajari. Hasil belajar pada siklus I, didapatkan nilai rata-rata kelas 76,2 dengan 
presentase ketuntasan sebesar $52,4 \%$. Berdasarkan aktiftas pada siklus 1 , didapat data sebagai berikut:

Tabel 2. Hasil Belajar Siklus I

\begin{tabular}{cccccccc}
\hline \multirow{2}{*}{ No } & Siswa & \multicolumn{5}{c}{ Soal } & \multirow{2}{*}{ skor } \\
\cline { 3 - 6 } & & 1 & 2 & 3 & 4 & 5 & \\
\hline 1 & Siswa 1 & 20 & 20 & 20 & 10 & 0 & 70 \\
2 & Siswa 2 & 20 & 20 & 10 & 20 & 0 & 70 \\
3 & Siswa 3 & 20 & 20 & 0 & 20 & 0 & 60 \\
4 & Siswa 4 & 20 & 20 & 10 & 10 & 10 & 70 \\
5 & Siswa 5 & 20 & 20 & 0 & 20 & 20 & 80 \\
6 & Siswa 6 & 20 & 20 & 20 & 0 & 20 & 80 \\
7 & Siswa 7 & 20 & 20 & 0 & 10 & 10 & 60 \\
8 & Siswa 8 & 20 & 20 & 20 & 10 & 10 & 80 \\
9 & Siswa 9 & 20 & 20 & 20 & 20 & 10 & 90 \\
10 & Siswa 10 & 20 & 20 & 0 & 20 & 20 & 80 \\
11 & Siswa 11 & 20 & 20 & 20 & 0 & 10 & 70 \\
12 & Siswa 12 & 20 & 20 & 20 & 10 & 0 & 70 \\
13 & Siswa 13 & 20 & 20 & 10 & 20 & 20 & 90 \\
14 & Siswa 14 & 20 & 20 & 20 & 20 & 10 & 90 \\
15 & Siswa 15 & 20 & 20 & 0 & 20 & 10 & 70 \\
16 & Siswa16 & 20 & 20 & 0 & 20 & 10 & 70 \\
17 & Siswa 17 & 20 & 20 & 10 & 20 & 20 & 90 \\
18 & Siswa 18 & 20 & 20 & 0 & 20 & 20 & 80 \\
19 & Siswa 19 & 20 & 0 & 20 & 20 & 10 & 70 \\
20 & Siswa 20 & 20 & 20 & 20 & 10 & 10 & 80 \\
21 & Siswa 21 & 20 & 10 & 10 & 20 & 20 & 80 \\
& & & Rata-rata kelas & & & & 76,2 \\
\hline
\end{tabular}

Tabel 3. Tabulasi Nilai Siklus I

\begin{tabular}{ccccc}
\hline No & Skor (S) & Frekuensi & $\begin{array}{c}\text { Prosentase } \\
(\%)\end{array}$ & S x F \\
\hline 1 & 50 & - & - & - \\
2 & 60 & 2 & $10 \%$ & 120 \\
3 & 70 & 8 & $38 \%$ & 560 \\
4 & 80 & 7 & $33 \%$ & 560 \\
5 & 90 & 4 & $19 \%$ & 360 \\
6 & 100 & - & - & - \\
& Jumlah & 21 & $100 \%$ & 1600 \\
\hline
\end{tabular}

keterangan:

$\mathrm{S} \times \mathrm{F}=$ skor $\mathrm{x}$ frekuensi

skor rata-rata $=1590: 21=76,2$

Berdasarkan tabel 3 tentang tabulasi nilai siklus I, didapatkan bahwa ada 10 siswa yang belum memenuhi KKM yang ditentukan atau sebesar $47,6 \%$. Siswa yang belum tuntas yakni mendapat nilai 60 untuk 2 orang, dan nilai 70 untuk 8 orang. Sedangkan siswa yang sudah tuntas sebanyak 11 orang atau sebesar $52,4 \%$. Berdasarkan hasil belajar siklus I dapat diketahui bahwa rata-rata kelas mengalami kenaikan dibandingkan dengan hasil belajar pra siklus, rata-rata kelas yang didapatkan pada siklus I adalah 76,2. Meski demikian, hasil tersebut dirasa belum maksimal 
dikarenakan masih ada siswa yang belum tuntas, oleh karena itu penulis melaksanakan siklus ke II.

Pembelajaran pada siklus II merupakan kelanjutan dari siklus I dan pembaharuan dengan menambah waktu dalam mengamati video pembelajaran dan gambar yang relevan dengan materi yang diajarkan. Secara umum, pembelajaran pada siklus II hampir sama dengan siklus I. Aktifitas belajar pada siklus II adalah 1) mereview materi sebelumnya dengan metode tanya jawab, 2) mengamati video tentang sistem peredaran darah pada manusia, 3) mengamati gambar tentang gangguan peredaran darah, 4) siswa mengerjakan tes tertulis. Hasil belajar pada siklus II, didapatkan nilai rata-rata kelas adalah 88,1 atau $100 \%$ siswa telah memenuhi KKM. Hasil belajar pada siklus II dapat dilihat pada tabel di bawah ini:

Tabel 4. Hasil Belajar Siklus II

\begin{tabular}{cccccccc}
\multirow{2}{*}{ No } & Siswa & \multicolumn{5}{c}{ Soal } & \multirow{2}{*}{ skor } \\
\cline { 3 - 6 } & & 1 & 2 & 3 & 4 & 5 & \\
\hline 1 & Siswa 1 & 20 & 20 & 20 & 10 & 10 & 80 \\
2 & Siswa 2 & 20 & 20 & 20 & 20 & 10 & 90 \\
3 & Siswa 3 & 20 & 20 & 20 & 10 & 10 & 80 \\
4 & Siswa 4 & 20 & 20 & 20 & 10 & 10 & 80 \\
5 & Siswa 5 & 20 & 20 & 20 & 20 & 10 & 90 \\
6 & Siswa 6 & 20 & 20 & 20 & 20 & 10 & 90 \\
7 & Siswa 7 & 20 & 20 & 20 & 10 & 10 & 80 \\
8 & Siswa 8 & 20 & 20 & 20 & 10 & 20 & 90 \\
9 & Siswa 9 & 20 & 20 & 20 & 20 & 20 & 100 \\
10 & Siswa 10 & 20 & 20 & 20 & 20 & 10 & 90 \\
11 & Siswa 11 & 20 & 20 & 20 & 10 & 10 & 80 \\
12 & Siswa 12 & 20 & 20 & 20 & 10 & 10 & 80 \\
13 & Siswa 13 & 20 & 20 & 20 & 20 & 20 & 100 \\
14 & Siswa 14 & 20 & 20 & 20 & 20 & 20 & 100 \\
15 & Siswa 15 & 20 & 20 & 20 & 20 & 10 & 90 \\
16 & Siswa 16 & 20 & 20 & 20 & 10 & 10 & 80 \\
17 & Siswa 17 & 20 & 20 & 20 & 20 & 20 & 100 \\
18 & Siswa 18 & 20 & 20 & 20 & 10 & 20 & 90 \\
19 & Siswa 19 & 20 & 20 & 20 & 20 & 0 & 80 \\
20 & Siswa 20 & 20 & 20 & 20 & 10 & 20 & 90 \\
21 & Siswa 21 & 20 & 20 & 20 & 20 & 10 & 90 \\
& & & Rata-rata kela & & & & 88,1 \\
\hline
\end{tabular}

Tabel 5. Tabulasi Nilai Siklus II

\begin{tabular}{ccccc}
\hline No & Skor (S) & Frekuensi & $\begin{array}{c}\text { Prosentase } \\
(\%)\end{array}$ & S x F \\
\hline 1 & 50 & - & - & - \\
2 & 60 & - & - & - \\
3 & 70 & - & - & - \\
4 & 80 & 8 & $38 \%$ & 640 \\
5 & 90 & 9 & $43 \%$ & 810 \\
6 & 100 & 4 & $19 \%$ & 400 \\
& Jumlah & 21 & $100 \%$ & 1850 \\
\hline
\end{tabular}


keterangan:

$\mathrm{S} \times \mathrm{F}=$ skor $\mathrm{x}$ frekuensi

skor rata-rata $=1850: 21=88,1$

Berdasarkan tabulasi nilai siklus II dapat diketahui bahwa seluruh siswa telah memenuhi KKM dengan rincian 8 siswa mendapat nilai 80, 9 siswa mendapat nilai 90 dan 4 siswa mendapat nilai 100 dengan rata-rata kelas adalah 88,1. Hal ini berarti terjadi peningkatan hasil belajar dibandingkan dengan siklus I dimana rata-rata kelasnya adalah 76,2 . Untuk lebih jelasnya dapat dilihat pada diagram batang di bawah ini:

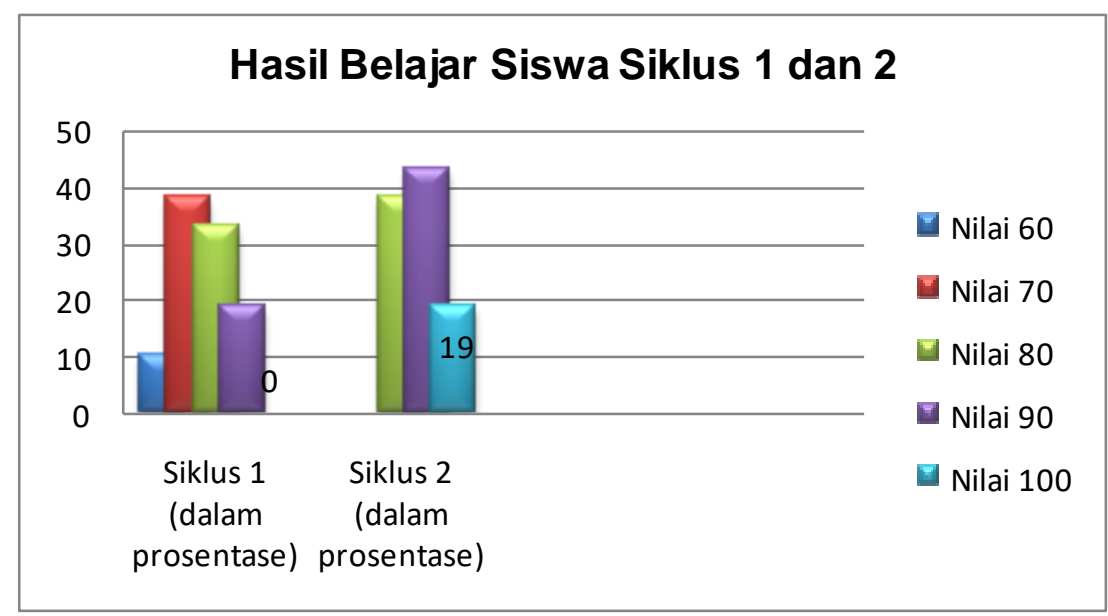

Gambar 1. hasil belajar siswa pada siklus 1 dan siklus 2

Berdasarkan penelitian dapat diketahui bahwa terjadi peningkatan hasil belajar siswa pada mata pelajaran IPA tentang Organ Peredaran Darah, hal ini dapat dilihat pada tabel 1. Pada pra siklus nilai rata-rata kelas adalah 70,0 dengan 15 siswa di bawah KKM (71\%) dan 6 siswa di atas KKM (29\%). Sedangkan pada siklus I rata-rata kelas naik menjadi 76,2 dengan rincian 10 siswa masih di bawah KKM (47,6\%) dan 11 siswa sudah sesuai KKM $(52,4 \%)$ dan pada siklus li rata-rata kelas naik menjadi 88,1 atau $100 \%$ siswa telah sesuai KKM.

Sesuai dengan data penelitian, analisis data penelitian dan pembahasan data penelitian di atas, penulis memperoleh hasil penelitian bahwa dengan mengoptimalkan media audiovisual dan media gambar dapat meningkatkan hasil belajar siswa pada materi IPA kelas V SDIT Harapan Bunda Purwokerto. Hal ini sejalan dengan hasil penelitian tindakan kelas yang dilakukan oleh Irwandi (2007)"...bahwa penggunaan media audio visual sangat cocok digunakan pada pembelajaran dan dapat meningkatkan hasil belajar siswa..."(dalam Jurnal IImiah, 7144-17114-1-SM)

Senada dengan pendapat Musfiqon (2012, hlm. 187) mengemukakan bahwa "...pembelajaran yang menggunakan multimedia telah terbukti lebih efektif dan efisien serta bisa meningkatkan hasil belajar siswa". Serta pendapat daroi Benni Agus Pribadi (dalam Musfiqon 2012), media pembelajaran berfungsi untuk membantu memudahkan belajar bagi siswa dan juga memudahkan proses pembelajaran bagi guru, memberikan pengalaman lebih nyata (abstrak menjadi konkret, menarik perhatian siswa lebih besar (jalannya pelajaran tidak membosankan), semua indera siswa dapat diaktifkan, dapat membangkitkan dunia teori dengan realitanya 


\section{SIMPULAN}

Berdasarkan hasil analisis dapat ditarik kesimpulan bahwa melalui media gambar dan audiovisual dapat meningkatkan hasil belajar siswa. Pada siklus I beberapa siswa masih di bawah KKM yang telah ditentukan dengan rata-rata kelas 76,2. Sedangkan pada siklus II semua siswa kelas V SDIT Harapan Bunda Purwokerto pada mata pelajaran IPA telah memenuhi KKM yakni dengan rata-rata kelas adalah 88,1.

Guna mencapai hasil belajar yang optimal, seorang pendidik atau guru hendaknya:

a) Guru dalam mengajar hendaknya menggunakan metode mengajar yang tepat, bervariasi dan mengikuti perkembangan jaman.

b) Guru dalam mengajar hendaknya mempersiapkan segala sesuatunya dengan baik.

c) Guru harus mampu memotivasi siswa agar siswa memberikan respon yang baik terhadap pelajaran di kelas sehingga tujuan pembelajaran dapat tercapai dengan maksimal.

\section{DAFTAR PUSTAKA}

Ahmad Fujiyanto, Asep Kurnia Jayadinata, Dadang Kurnia, (2016). Penggunaan Media Audio Visual Untuk Meningkatkan Hasil Belajar Siswa Pada Materi Hubungan Antarmakhluk Hidup, Jurnal Pena IImiah: Vol. 1, No, 1

Azhar Arsyad. 2013. Media Pembelajaran. Jakarta: Rajawali Pers.

Djamarah Syaifudin Bahri. (2010). Strategi Belajar Mengajar, Jakarta: Rineka Cipta. 2010)

Irwandi. (2007) Penggunaan Media Audio Visual Dalam Peningkatan Hasil Belajar Materi Rukun Iman Pada Siswa Kelas I Sd Negeri 49 Kota Banda Aceh, Fakultas Tarbiyah dan Keguruan UIN Ar-raniry Banda Aceh, Jurnal IImiah 7144-17114-1SM

Mudjono dan Dimyati. (2009). Belajar dan Pembelajaran. Jakarta: Rineka Cipta

Musfiqon. (2012). Pengembangan Media \& Sumber Pembelajaran. Jakarta. Prestasi Pustaka Raya.

Oemar Hamdik. (2003). Proses Belajar Mengajar. Jakarta: PT. Bumi Aksara

Pupuh Fathurrohman \& Sobry Sutikno, Strategi Belajar Mengajar, (Bandung: PT Refika Aditama, 2007)

Save M, Dagun, (2006) Kamus Besar Ilmu Pengetahuan. Jakarta: Lembaga Pengkajian Kebudayaan Nusantara (LPKN)

Sujana, Atep. (2014). Pendidikan IPA Teori dan Praktek. Sumedang. Rizqi Press.

Sutirman, (2013) Media dan Model-model Pembelajaran Inovatif, Yogyakarta: Graha IImu. 